(RESEARCH ARTICLE)

\title{
Activities of neem and wood ash as biopesticides in the control of insect pests on vegetable crops in Mubi
}

\author{
Wahedi Jasini Alexander 1*, Zakariya Rebecca 2, Elkanah Obadiah Sambo ${ }^{3}$, Ishuwa Miriam Nguuma 4 , \\ Vincent Victor Miyananiyi ${ }^{1}$ and Enoch Tumuma Godobe ${ }^{1}$ \\ ${ }^{1}$ Department of Zoology, Adamawa State University, Mubi, Nigeria \\ 2 Department of Botany, Ahmadu Bello University, Zaria, Nigeria \\ ${ }^{3}$ Department of Biological Sciences, Taraba State University Jalingo, Nigeria \\ ${ }^{4}$ Department of Biological Sciences, University of Mkar, Gboko, Nigeria
}

Publication history: Received on 27 August 2017; revised on 05 October 2017; accepted on 09 October 2017

https://doi.org/10.30574/gscbps.2017.1.1.0006

\begin{abstract}
The study was carried out to evaluate the efficacy of neem and wood ash for the control of insect pests infesting three vegetables in the gardening; okra, spinach and sorrel. The plants were sown in a randomize complete block design (RCBD) with four replications. Treatment application starts immediately after germination and continued on 3 days interval. Parameters observed were number of damages and number of insect infestation. These were noted after 6 and 9 weeks of germination. Data collected was analyzed using analysis of variance (ANOVA). The results revealed that there was a significant difference $(\mathrm{P}>0.05)$ in the number of damages as well as number of insect pests encountered. Wood ash proved to be more effective in protecting the vegetables against insect pests, since it recorded significant minimum activities of insect pests. Therefore, botanicals such as neem and wood ash could be considered as an effective in alternative method of pest management. The use of biopesticides generally is encouraged since they can proffer solution of controlling insect pest without any environmental concern.
\end{abstract}

Keywords: Biopesticides; Neem; Insect pest; Vegetables; Wood ash

\section{Introduction}

In the garden, economic plants such as root vegetables, leaf vegetables, fruits and herbs are grown for human consumption. They are vital supplements require for the support of human wellbeing and prevention of disease [1], since they contain important food ingredients which can be effectively used to develop and repair the body [2]. In most countries of the world especially in Nigeria, the production of vegetables is on the increase as it remains one of the staple food components [3]. According to Kebede and Gan, the main sources of farm income for small and limited resource farmers in most parts of the world are basically arable crops production, vegetables and vegetable crops [4].

Okra (Abelmoschus esculentus), spinach (Spinacia oleracea) and sorrel (Rumex acetosa) are some of the important vegetable crops that are utilized by human in households on daily basis especially in the sub-Saharan Africa [5-6]. They are the most commonly grown vegetable crops in the tropics [7]. Their cultivation and production has been widely practiced because of their importance to the economy development and can be found in almost every market in Africa, especially Nigeria [8-9]. They are rich in protein, vitamins, and minerals [10-11].

\footnotetext{
*Corresponding author

E-mail address: wahedijasini@ gmail.com
} 
Despite the economic importance of these tree plants (Abelmoschus esculentus, Rumex acetosa and Spinacia oleraceae) to humans, the cultivation of these vegetable crops are heavily affected because of the attack by the insect pests, thereby affecting their growth and development, yield performance and market values. Therefore, there is need to protect these vegetables against insects pest attack in the garden so as to produce high yield and insect free/healthy vegetable crops.

Over the years, chemical insecticides have been widely used to control insect pests both in the field and in the store, but unfortunately, the danger of the misuse of insecticides especially to the ecosystem and human health has made farmers and researchers to find an alternative control measure are safe, readily available and biodegradable. The use of neem (Azadirachta indica) and other biopesticides against insect pests of vegetables is gaining much attention [12]. Neem is known for its insecticidal properties against stored product, pests, stem borer etc but little is known on its repellent effect against insects infesting garden plants. Again, there is no much report on the insecticidal properties of wood ash especially on garden plants. Therefore, this study was designed to evaluate the repellant efficacy of neem leaf powder and wood ash on insects infesting garden plants in Mubi.

\section{Materials and methods}

\subsection{Study area}

The study was carried out in the Biological Sciences Research Garden of the Adamawa State University, Mubi, Nigeria. Mubi lies between latitude $10^{\circ} 32^{\prime} \mathrm{N}$ and $10^{\circ} 11^{\prime} \mathrm{N}$ and longitude $13^{\circ} 12^{\prime} \mathrm{E}$ and $13^{\circ} 35^{\prime} \mathrm{E}$ [13]. It has a tropical climate which is determined by the movement of Inter Tropical Convergence Zone (ITCZ) as well as the effect of relief. It is characterized by two seasons, wet and dry season. Rainfall start in April, progressing and attaining its height in August and stop usually in October. Regular annual rainfall levels between $998 \mathrm{~mm}$ and $1262 \mathrm{~mm}$ [13].

\subsection{Collection of materials}

Clean seeds of okra, spinach and sorrel were bought from Mubi market, Mubi North, Adamawa state and were treated with seed dressing chemical (Apron Star 42WS) before planting. Fresh neem leaves were collected from the Botanical Research Garden in Adamawa State University, Mubi. These leaves were dried properly in a cupboard in the Biological Sciences Laboratory under room temperature. Thereafter, these leaves were ground into fine powder using electric blender and stored in a plastic container with screw cap top. Wood ash was obtained from burnt fire wood use for cooking; sieved to remove particles/stone and were stored in plastic container properly. The synthetic insecticide (Rambo: permethrin $0.60 \%$ ) was purchased from agro chemical sell outlet in Mubi main market, and was used as the positive control.

\subsection{Land preparation}

The land used is located at the Botanical Garden, Adamawa State University Campus Mubi. The land was ploughed and harrowed and was mapped into plots of randomized complete block design, and a measurement of $27 \mathrm{~m} \mathrm{x} 19 \mathrm{~m}$ was demarcated from the ploughed and harrowed land. This was marked into four plots as replicates per crop (with pegs), to make a total of twelve plots. Each replicate plot contains four plant holes to make a total of 36 plant holes. The distance between each plant hole measures $4 \mathrm{~m}$ and $1 \mathrm{~m}$ alley between each replicate plot. After the demarcation, the treatment plots were bounded and remolded and was ready for planting.

\subsection{Seed planting}

Planting commenced immediately after land preparation. The inter and intra-row spacing was $100 \mathrm{~cm}$ and $50 \mathrm{~cm}$, respectively. Three to five seeds were sown in each planting hole.

\subsection{Treatment application}

Treatment application started 7 days after germination for each plant. The treatments $(20 \mathrm{~g})$ were applied at 3 days interval, and lasted for 30 days before the readings were taken after 6 and 9 weeks of treatment application. This was carried out in the morning between $6 \mathrm{am}$ and $9 \mathrm{am}$. The treatments were applied gently on the leaves and stems of the plants manually using hand. It was ensured that the treatments were applied gently on the right plants to avoid wind blowing across the other plots.

\subsection{Data collection}

Data were collected on the following parameters: 
Numbers of damages encountered were noted after 6 weeks and 9 weeks of germination. The types of damages include bored holes on the leaves and stems.

Numbers of insects encountered were noted simultaneously with damages ( 6 weeks and 9 weeks after germination) and was recorded accordingly.

\subsection{Data analysis}

Data was analyzed using Analysis of Variance (ANOVA) with Statistical Analysis Software (SAS). The mean differences were separated using Least Significant Difference (LSD) at $5 \%$ level of significance $(\mathrm{P}>0.05)$.

\section{Results}

Table 1 shows the effects of neem leaf powder and wood ash in the protection of garden plants against insect damage. There was a significant difference $(\mathrm{P}>0.05)$ in the number of damages recorded on the three crops treated with neem and wood ash after 6 and 9 weeks of monitoring when compared with the control (untreated experiment). However, the synthetic chemical (Rambo) significantly $(\mathrm{P}>0.05)$ reduced the number of damages to the minimum $(0.25 \pm 0.50)$ after 9 weeks on okra, and spinach, respectively; and no damage was encountered on sorrel after weeks of treatment with the synthetic chemical. After 9 weeks of monitoring, the damages recorded on the treated plants did not differ significantly $(\mathrm{P}>0.05)$, but the control (untreated) significantly recorded higher number of damages.

Table 1 Effects of neem leaf powder and wood ash in the protection of garden plants against insect damage

\begin{tabular}{lcccccc}
\hline \multirow{2}{*}{ Treatment } & \multicolumn{2}{c}{ Okra (Abelmoschus esculentus) } & \multicolumn{2}{c}{ Sorrel (Rumex acetosa) } & \multicolumn{2}{c}{ Spinach (Spinacia oleracea) } \\
\cline { 2 - 6 } & $\mathbf{6}$ weeks & $\mathbf{9}$ weeks & $\mathbf{6 ~ w e e k s}$ & $\mathbf{9 ~ w e e k s}$ & $\mathbf{6}$ weeks & $\mathbf{9}$ weeks \\
\hline $\begin{array}{l}\text { Control } \\
\text { (untreated) }\end{array}$ & $24.25 \pm 3.10^{\mathrm{b}}$ & $32.75 \pm 5.12^{\mathrm{b}}$ & $26.50 \pm 2.65^{\mathrm{b}}$ & $28.75 \pm 2.22^{\mathrm{b}}$ & $22.25 \pm 3.59^{\mathrm{b}}$ & $37.75 \pm 6.13^{\mathrm{b}}$ \\
Neem leaf & $3.75 \pm 0.96^{\mathrm{a}}$ & $1.00 \pm 0.82^{\mathrm{a}}$ & $3.00 \pm 0.82^{\mathrm{a}}$ & $0.25 \pm 0.50^{\mathrm{a}}$ & $4.75 \pm 0.96^{\mathrm{a}}$ & $1.00 \pm 0.82^{\mathrm{a}}$ \\
Wood ash & $3.00 \pm 1.41^{\mathrm{a}}$ & $0.75 \pm 0.96^{\mathrm{a}}$ & $2.75 \pm 1.26^{\mathrm{a}}$ & $0.50 \pm 0.58^{\mathrm{a}}$ & $3.25 \pm 1.26^{\mathrm{a}}$ & $1.00 \pm 0.82^{\mathrm{a}}$ \\
Rambo & $1.25 \pm 0.96^{\mathrm{a}}$ & $0.25 \pm 0.50^{\mathrm{a}}$ & $1.75 \pm 1.50^{\mathrm{a}}$ & $0.00 \pm 0.00^{\mathrm{a}}$ & $2.00 \pm 0.82^{\mathrm{a}}$ & $0.25 \pm 0.50^{\mathrm{a}}$ \\
LSD & 0.090 & 0.710 & 0.341 & 0.577 & 0.089 & 0.753 \\
\hline
\end{tabular}

Table 2 Efficacy of neem leaf powder and wood ash in the protection of garden plants against insect infestation

\begin{tabular}{lcccccc}
\hline \multirow{2}{*}{ Treatment } & \multicolumn{2}{c}{ Okra (Abelmoschus esculentus) } & \multicolumn{2}{c}{ Sorrel (Rumex acetosa) } & \multicolumn{2}{c}{ Spinach (Spinacia oleracea) } \\
\cline { 2 - 6 } & $\mathbf{6}$ weeks & $\mathbf{9}$ weeks & $\mathbf{6 ~ w e e k s}$ & $\mathbf{9}$ weeks & $\mathbf{6}$ weeks & $\mathbf{9}$ weeks \\
\hline $\begin{array}{l}\text { Control } \\
\text { (untreated) }\end{array}$ & $21.00 \pm 2.94^{\mathrm{b}}$ & $18.50 \pm 2.38^{\mathrm{b}}$ & $15.75 \pm 5.74^{\mathrm{b}}$ & $18.50 \pm 3.70^{\mathrm{b}}$ & $13.75 \pm 4.35^{\mathrm{c}}$ & $18.50 \pm 2.38^{\mathrm{b}}$ \\
Neem leaf & $4.00 \pm 0.82^{\mathrm{a}}$ & $0.75 \pm 0.96^{\mathrm{a}}$ & $3.75 \pm 1.71^{\mathrm{a}}$ & $0.25 \pm 0.50^{\mathrm{a}}$ & $7.00 \pm 1.16^{\mathrm{b}}$ & $1.00 \pm 0.82^{\mathrm{a}}$ \\
Wood ash & $2.50 \pm 1.00^{\mathrm{a}}$ & $0.75 \pm 0.96^{\mathrm{a}}$ & $2.00 \pm 1.16^{\mathrm{a}}$ & $0.25 \pm 0.50^{\mathrm{a}}$ & $3.50 \pm 1.29^{\mathrm{ab}}$ & $0.50 \pm 0.58^{\mathrm{a}}$ \\
Rambo & $1.75 \pm 0.96^{\mathrm{a}}$ & $0.75 \pm 0.96^{\mathrm{a}}$ & $1.50 \pm 0.58^{\mathrm{a}}$ & $0.50 \pm 0.58^{\mathrm{a}}$ & $2.75 \pm 1.26^{\mathrm{a}}$ & $1.25 \pm 0.96^{\mathrm{a}}$ \\
LSD & 0.095 & 1.000 & 0.342 & 0.863 & 0.064 & 0.512 \\
\hline \multicolumn{4}{c}{ Means carrying the same alphabet along the column are not significantly different $(\mathrm{P}>0.05)$}
\end{tabular}

In Table 2, the mean total number of insects recorded from the 6 and 9 weeks of collection is shown. Generally, there was a significant difference $(\mathrm{P}>0.05)$ in the number of insects recorded on the treated plants and the untreated control after 6 and 9 weeks of monitoring. However, the number of insects recorded at 6 weeks of collection on spinach revealed a significant difference $(\mathrm{P}>0.05)$ across the treatments. After 9 weeks of monitoring, both neem and wood ash significantly reduced $(0.25 \pm 0.50)$ the number of insect infestation on sorrel more than Rambo (the synthetic chemical) which recorded $0.50 \pm 0.58$ mean number of insects. Compared with the control untreated, the plant treatments significantly $(\mathrm{P}>0.05)$ reduced both the damages on the plants as well as insect pests infestation. 


\section{Discussion}

Comparison of the repellent and protective effect of neem leaf powder and wood ash on three garden plants in Mubi revealed that there was no significant difference $(\mathrm{P}>0.05)$. However, compared to the control untreated experiment, the treatments showed some promising effects in the protection of garden plants against insect infestation and damages. This suggests that the neem leaf powder as well as the wood ash contain some insecticidal properties. The repellent effect exhibited by neem products against insect pests has been reported by several authors like Zillur and Shamin [14], Ganguli [15], Mochiah et al. [16] etc, who reported that neem does not usually kill insects straight but rather it repels them and that could affect their growth and development. The protectant effect shown by wood ash on vegetable crops in this study agrees with the works of Mochiah et al. reported a significant reduction of insect pest infestation on vegetable crops [16]. The protectant effect shown by wood ash in the study also agrees with Wini et al., where wood ash successfully controlled Sitophilus zeamais in stored maize [17]. The protectant effect could be as a result of the presence of potash which contains potassium as reported by Hume [18].

It was also revealed from this study that spinach was more susceptible to insect attack as well as the number of damages. This could be that spinach has an attractive component that attracts insect infestation. The order of the susceptibility of garden plants to damage and insect infestation is as follows: spinach>okra >sorrel. The study also revealed that wood ash protected the garden plants more than the neem leaf powder as shown in Table 1 and 2 . The wood ash significantly $(\mathrm{P}>0.05)$ reduced the activities of the insects on the garden plants confirming its effectiveness as insecticidal. The order of the efficacy of the treatment including the synthetic chemical (Rambo: permethrin $0.60 \%$ ) in this study is as follows: synthetic chemical (Rambo: permethrin $0.60 \%$ ) > wood ash $>$ neem leaf powder.

\section{Conclusion}

In light of the above results from this study, it is obvious that the treatments showed some promising effect in both the protection of garden plants against insect infestation and number of damage encountered. Although, the comparison of the repellent and protective effect of neem leaf powder showed no significant difference $(P>0.05)$, the wood ash however protected the garden plants more than neem leaf powder as it significantly recorded less damage and fewer number of insects on the garden plants, all but confirmed their efficacy.

\section{Compliance with ethical standards}

\section{Acknowledgments}

The authors wish to acknowledge the contribution of Mr. Bayaso of Ministry of Agriculture, Adamawa State, Nigeria for performing the statistical analysis.

\section{Disclosure of conflict of interest}

This work was carried out in collaboration between all authors. 'Author Wahedi JA' designed and supervised the study, wrote the protocol, and wrote the first draft of the manuscript. 'Author Zakariya R and Enoch TG' carried out the experiment. 'Author Elkanah OS', 'Author Vincent VM' and 'Author Ishuwa MN' managed the literature searches. All authors read and approved the final manuscript.

\section{References}

[1] Bakhru HK. (2003). Food that heals: the natural way to good health. Orient paperback, Delhi, 82-90.

[2] Etim NA and Edet GE. (2007). Estimating the determinant of poverty among peri-urban Telferia, occidentalis farmers in Uyo, Nigeria. Proceedings of $41^{\text {st }}$ Conference of Agricultural Society of Nigeria, Samaru, 434-436.

[3] Udoh EJ and Akpan, SB. (2007). Measuring the technical efficiency of waterleaf production in Akwa Ibom State, Nigeria. American Eurasian Journal of Agriculture and Environmental Science, 2 (5), 578.

[4] Kebede E and Gan J. (1999). The economic potential of vegetable production for limited resource farmers in south central Alabama. Journal of Agribusiness, 17, 63-75.

[5] Babatunde RO, Omotesho OA and Sholotan OS. (2007). Socio economic characteristics and food security status, north central Nigeria. Pakistan Journal of Nutrition, 6(1), 16. 
[6] Obopile M, Munthali DC and Matilo B. (2008). Farmers' knowledge, perceptions and management of vegetable pests and diseases in Botswana. Crop Protection, 27, 1220 -1224.

[7] Gibbon D and Pain A. (1984). Crops of drier regions of the tropics. Longman, London, 137.

[8] Chrisco EL and Onuh MO. (2005). Influence of Plant spacing on the growth and yield of okra Abelmoschus esculentus (L) Moench. Proceedings of the 39th Conference of the Agricultural Society of Nigeria (ASN), 612-615.

[9] Udoh DJ, Ndon BA, Asuquo PE and Ndaeyo NU. (2005). Crop production techniques for the tropics. Concept Publishers, Lagos, Nigeria, 223-247.

[10] Martin FW. (1982). Okra, potential multipurpose crop for the temperate zones and tropics. Economic Botany, $36(3), 340-345$.

[11] Mbah EU, Nottindge DO and Keke CI. (2009). Growth and yield of cassava and okra as influenced by cassava varieties, in cassava/okra inter crop on an acid ultisol, Proceedings of the 43 ${ }^{\text {rd }}$ Annual Conference of Agricultural Society of Nigeria (ASN), Abuja, 19-23.

[12] Coulibaly O, Cherry AJ, Nouhoheflin T, Aitchedji CC and Al-Hassan R. (2007). Vegetable producer perceptions and willingness to pay for biopesticides. International Journal of Vegetable Science, 12(3), $27-42$.

[13] Adebayo AA. (2004). Mubi A Geographical Synthesis. 1 ${ }^{\text {st }}$ Edition paracelete Publishers. Yola, Nigeria, 1-19.

[14] Zillur R and Shamin, MJ. (1996). Neem in Unani medicine. Neem Research and Development Society of Pesticide Science, India, New Delhi, Edited by N. S Randhawa and B. S. Parmar. 2nd Revised Ed, Chapter 21, 208-219.

[15] Ganguli S. (2002). Neem: A therapeutic for all seasons. Current Science, 82(11), 1304.

[16] Mochiah MB, Banful B, Fening KN, Amoabeng BW, Offei Bonsu K, Ekyem S, Braimah H and Owusu-Akyaw M. (2011). Botanicals for the management of insect pests in organic vegetable production. Journal of Entomology and Nematology, 3 (6), 85-97.

[17] Wini GJ, Nukenine EN, Ndjonka D, Suh C and Cornel A. (2015). Efficacy of diatomaceous earth and wood ash for the control of Sitophilus zeamais in stored maize. Journal of Entomology and Zoology Studies, 3(5), $390-397$.

[18] Hume E. (2006). Wood Ashes: How to use them in garden. (http://www.humeseeds.com/ashes.htm).

\section{How to cite this article}

Wahedi JA, Zakariya R, Elkanah OS, Ishuwa MN, Vincnt VM and Enoch TG. (2017). Activities of neem and wood ash as biopesticides in the control of insect pests on vegetable crops in Mubi. GSC Biological and Pharmaceutical Sciences, 1(1), 06-10. 